\title{
Peran buzzer dan konstruksi pesan viral dalam proses pembentukan opini publik di new media
}

\author{
Ade Faulina ${ }^{\left.1^{*}\right)}$, Emeraldy Chatra ${ }^{1}$, Sarmiati Sarmiati ${ }^{1}$ \\ ${ }^{1}$ Pascasarjana Ilmu Komunikasi, Universitas Andalas, Padang, Indonesia
}

\begin{tabular}{l}
\hline Article Info \\
\hline Article history: \\
Received Des $12^{\text {th }}, 2021$ \\
Revised Des $26^{\text {th }}, 2021$ \\
Accepted Jan $19^{\text {th }}, 2022$ \\
\hline
\end{tabular}

\section{Keyword:}

Buzzer

Opini publik

New media

Warganet

Konstruksi pesan

\begin{abstract}
Buzzer merupakan istilah yang dewasa ini mudah dikenali oleh siapa saja. Kehadiran buzzer tidak terlepas dari penggunaan gawai di kalangan masyarakat atau yang dikenal dengan netizen. Aktivitas netizen di new media atau internet menyebabkan buzzer menjadi fenomena yang terus ada dan berkembang saat ini. Apa yang dilakukan buzzer semula hanya sebagai bagian dari promosi atau pemasaran produk oleh perusahaan-perusahaan jasa atau barang. Namun hal itu berubah seiring kontestasi politik tanah air. Berbagai platform media sosial digunakan untuk menyampaikan pesan ataupun postingan. Penggunaan platform media sosial pun menjadi ruang publik untuk menyampaikan pendapat ataupun komentar sesuai kapasitas warganet itu sendiri. Kapasitas dan latar belakang yang berbeda menimbulkan keriuhan di jagat maya. Tidak jarang sampai menimbulkan konflik. Hal ini tidak lain karena percakapan tersebut mampu mengubah pandangan masyarakat atau opini publik. Besarnya pengaruh pesan yang disampaikan oleh buzzer dalam mengubah opini publik membuatnya layak untuk diteliti. Konstruksi pesan dalam pembentukan opini publik pada dasarnya telah dirancang sedemikian rupa untuk mencapai tujuan tertentu. Khususnya di dunia politik. Penelitian ini dilakukan dengan menggunakan metode penelitian kualitatif melalui pendekatan studi kasus. Dari penelitian diperoleh hasil bahwa konstruksi pesan yang dibuat oleh buzzer mampu untuk mengubah pandangan ataupun opini publik terhadap suatu hal ataupun narasi yang ada di tengah masyarakat.
\end{abstract}

(C) 2022 The Authors. Published by IICET.

This is an open access article under the CC BY-NC-SA license (https://creativecommons.org/licenses/by-nc-sa/4.0

\section{Corresponding Author:}

Faulina, A.,

Pascasarjana Ilmu Komunikasi, Universitas Andalas, Padang, Indonesia

Email: adefaulina@yahoo.com

\section{Pendahuluan}

Pro kontra dalam menyikapi kehadiran buzzer di tanah air memang masih belum berakhir. Buzzer dengan segala peran yang dimilikinya justru semakin mendapatkan tempat. Terlebih dengan berkembang dan ramainya penggunaan gawai di kalangan masyarakat atau netizen (warganet). Hasil riset dan laporan terbaru dari We are Social Hootsuite yang dirilis pada Januari 2020 menyatakan bahwa ada sekitar 175,4 juta pengguna internet di Indonesia. Data ini mengalami kenaikan dibanding tahun sebelumnya yaitu sebanyak $17 \%$ atau 25 juta pengguna internet di negeri ini (Haryanto 2020).

Apabila dihitung dari populasi Indonesia yaitu 272,1 juta jiwa, berarti $64 \%$ atau setengah penduduk tanah air telah mengakses dunia maya. Lebih lanjut disebutkan bahwa persentase pengguna internet yang berada dalam rentang usia 16 - 64 tahun ini menggunakan jenis teknologi informasi yang berbeda. Pengguna mobile phone sebanyak $96 \%$, smartphone $94 \%$, non-smartphone mobile phone berjumlah $21 \%$, laptop atau komputer 
desktop $66 \%$, table $23 \%$, konsol game sekitar $16 \%$, hingga virtual reality device sebanyak 5,1\%. Secara umum terdapat 338,2 juta penduduk Indonesia yang memiliki telepon seluler (ponsel), dan 160 juta di antaranya merupakan pengguna aktif media sosial.

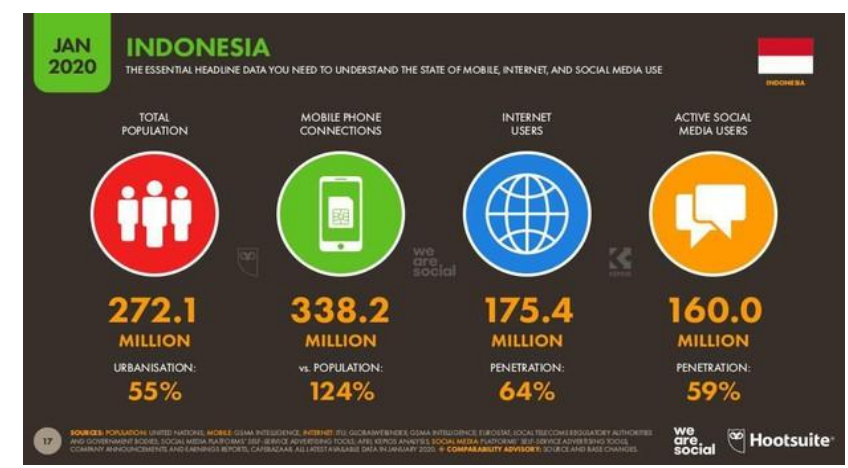

Sumber: (Haryanto 2020)

Gambar 1 <Hasil Riset We Are Social Hootsuite tentang Penggunaan Internet, Mobile Phone dan Media Sosial di Indonesia>

Rincian dari penggunaan gawai ini berkisar kepada platform (aplikasi/ fitur) YouTube, WhatsApp, Facebook, Instagram, Twitter, Line, FB Messenger, LinkedIn, Pinterest, We Chat, Snapchat, Skype, Tik Tok, Tumblr, Reddit dan Sina Weibo. Selain itu dari data tersebut juga didapati bahwa bahwa rata-rata pengguna internet menghabiskan 6 jam 43 menit untuk mengakses dunia siber. Sepertiga dari waktu online digunakan untuk mengakses media sosial, atau secara spesifik selama 2 jam 24 menit setiap harinya.

Media sosial secara sederhana (Syarief 2017) dapat diartikan sebagai media online yang mendukung interaksi sosial dengan menggunakan teknologi berbasis web yang mengubah komunikasi menjadi dialog interaktif. Adapun yang menjadi ciri-ciri dari media sosial tersebut antara lain : 1. Pesan yang disampaikan tidak hanya untuk satu orang, tapi juga kepada banyak orang. Seperti SMS ataupun internet, 2. Pesan yang disampaikan bebas, tanpa harus melalui gatekeeper, 3. Pesan yang disampaikan cenderung lebih cepat dibanding media lainnya, dan 4 . Penerima pesan menentukan waktu interaksi.

Menurut Kietzmann media sosial sebagai bagian dari media komunikasi massa juga memiliki beberapa fungsi yaitu : Pertama Identity adalah pengaturan identitas para pengguna (nama, usia, jenis kelamin, profesi, lokasi serta foto), Kedua Conversations yaitu pengaturan para pengguna berkomunikasi dengan pengguna lainnya dalam media sosial, Ketiga Sharing merupakan pertukaran, pembagian, serta penerimaan konten berupa teks, gambar, atau video yang dilakukan oleh para pengguna, Keempat Presence adalah kemampuan pengguna untuk mengakses pengguna lainnya. Fungsi selanjutnya, Kelima Relationship menggambarkan para pengguna terhubung atau terkait dengan pengguna lainnya, Keenam Reputation yaitu menggambarkan para pengguna dapat mengidentifikasi orang lain serta dirinya sendiri, dan Ketujuh Groups menggambarkan bahwa para pengguna dapat membentuk komunitas dan sub-komunitas yang memiliki latar belakang, minat dan demografi (Kietzmann et al. 2011).

Fungsi-fungsi yang dimiliki media sosial inilah yang kemudian membuka ruang bagi masyarakat untuk menggunakan gawai yang mereka miliki. Tidak terkecuali bagi buzzer. Media sosial memungkinkan terjadinya ruang interaktif dengan sesama pengguna. Namun sayangnya berbeda dengan masyarakat awam, buzzer justru menggunakan platform media sosial ini untuk menyampaikan, memposting atau membagikan konten-konten negatif, provokatif ataupun membully.

Buzzer pada dasarnya mempunyai ungkapan lain seperti pasukan siber atau pendengung. berdasarkan artikel yang diterbitkan oleh www.kompas.com, Sabtu (5/10/2019) pengamat media sosial Enda Nasution mengungkapkan bahwa buzzer merupakan akun-akun di media sosial yang tidak mempunyai reputasi untuk dipertaruhkan (Bramasta 2019). Lalu menurut hasil penelitian Wasisto Raharjo Jati (2016) dalam "Aktivisme Kelas Menengah Berbasis Media Sosial: Munculnya Relawan dalam Pemilu 2014", buzzer sendiri termasuk salah satu aktor penting yang memainkan peran dalam membentuk isu maupun mengubah preferensi politik. Buzzer secara sederhana dapat diartikan sebagai personal atau kolektif yang berperan sebagai otak atau kreator wacana/ isu untuk dibicarakan oleh netizen dalam dunia maya. Ia dinamakan buzzer karena berkaitan dengan tugasnya dalam mendengungkan (buzzing) suatu isu atau wacana untuk diterima dan ditangkap publik sebagai konstruksi berpikir (Jati 2016).

Centre for Innovation Policy and Governance (CIPG) menyebutkan bahwa awal munculnya buzzer bersamaan dengan kelahiran Twitter pada 2009. Mulanya, buzzer berkembang menjadi sebuah strategi pemasaran untuk 
mempromosikan produk guna meningkatkan penjualan. Namun fungsi buzzer kemudian berubah pada tahun 2012 ketika pasangan Jokowi-Ahok menggunakan pasukan media sosial untuk mendorong segala wacana atau isu politik.

Pada satu dekade terakhir dapat dilihat bahwa buzzer mampu mengkonstruksi berbagai pesan yang hendak disampaikannya. Mulai dari pesan-pesan untuk pemasaran produk maupun salah satu cara pencitraan (branding) tokoh publik, selanjutnya kegiatan buzzer juga turut menyasar isu-isu yang menyangkut kepentingan publik. Peran buzzer bukan hanya untuk menaikkan angka penjualan produk, meningkatkan citra tokoh tertentu tetapi ironisnya juga mampu untuk menurunkan nilai suatu produk ataupun menjatuhkan citra tokoh tersebut.

Banyak pesan ataupun konten-konten tersebut dibuat ataupun dikonstruksi untuk menarik perhatian warganet agar merespon apa yang disampaikan oleh buzzer tersebut. Kerja buzzer yang seperti ini tidak lepas dari fakta bahwa setiap orang bebas bersuara ataupun berpendapat. Buzzer menjadi saluran komunikasi untuk oknum atau pihak-pihak tertentu untuk untuk membela diri ataupun mempertahankan suatu kebijakan di mata publik. Hal ini dapat dilihat dari adanya istilah "buzzer istana" yang disematkan kepada akun-akun maupun orang-orang tertentu yang relatif dinilai sebagai pihak yang menyokong setiap kebijakan yang dikeluarkan oleh pemerintah. Tanpa memandang apakah kebijakan itu menguntungkan (positif) maupun merugikan (negatif) bagi masyarakat.

Selain itu buzzer secara terkomando maupun tidak, dapat mempengaruhi masyarakat dalam melihat suatu permasalahan (isu) maupun menanggapinya. Beberapa contoh kasus yang sempat ramai dalam tiga tahun terakhir antara lain, tagar uninstall BukaLapak menjelang Pemilu 2019, pembully-an terhadap Gubernur Anies Baswedan tentang banjir Jakarta maupun isu covid 19. Buzzer di samping itu juga terlibat dalam mengkonstruksi ulang pesan yang tak jarang menjurus kepada hoax (berita bohong), fake news (berita palsu) maupun fitnah. Hal ini dapat dilihat dari berbagai isu yang ditujukan kepada Anies Baswedan. Sejak dilantik menjadi Gubernur DKI Jakarta pada hari Senin, 16 Oktober 2017 tidak sedikit isu yang dialamatkan kepada dirinya. Baik itu ketika ia masih berpasangan dengan Sandiaga Uno maupun ketika memimpin Jakarta seorang diri.

Kasus ambulans Pemprov DKI yang membawa batu dalam demonstrasi pada tanggal 24 September 2019 merupakan isu yang dimainkan oleh buzzer. Meskipun awalnya isu ini ditiupkan oleh Twitter akun resmi kepolisisan@TMCPoldaMetro pada pukul 02.15 WIB, namun satu jam sebelumnya isu ini telah lebih dahulu disampaikan oleh akun Twitter Denny Siregar yang memang dikenal sebagai seorang buzzer (Nailufar 2019). Isu ini bahkan sempat mengejutkan masyarakat yang kemudian terbelah. Sebagian masyarakat meyakini bahwa berita itu tidak benar. Sedangkan sebagian lainnya menuding bahwa pemerintah DKI Jakarta telah melakukan kejahatan. Perang opini oleh masyarakat ini reda karena kebenaran dari berita itu tidak dapat dibuktikan. Dan pihak Mabes Polri pun mengklarifikasi bahwa mereka telah salah tuduh.

Isu lain yang masih dibicarakan hingga saat ini adalah keberadaan virus corona atau covid-19. Dalam isu ini, buzzer turut memainkan perannya. Mulai dari ikut membela pemerintah bahwa Indonesia tidak mungkin terjangkit wabah virus corona, buzzer mengungkapkan bahwa apa yang dilakukan pemerintah telah maksimal hingga melakukan bullying ('penindasan') terhadap segala kebijakan yang dikeluarkan oleh Anies Baswedan dalam mengatasi meluasnya penyebaran wabah virus corona.

Masing-masing contoh menggambarkan bahwa buzzer dewasa ini bukan hanya fenomena biasa yang terjadi secara spontan. Sebagaimana yang dinyatakan dalma sejumlah penelitian di antaranya seperti penelitian Jati (2016) menunjukkan bahwa keberadaan buzzer tidak dapat dipisahkan dari cyberactivism, khususnya di media sosial. Aktivitas buzzer di media sosial khususnya bidang politik dewasa ini justru dilakukan oleh orang-orang dari kelas menengah yang secara sukarela menjadi aktor kuat dalam arena politik ekstra parlementer yang mempengaruhi citra Jokowi sebagai figur penting dan memuluskan suksesinya dalam Pemilu 2014 (Jati 2016).

Rieka Mustika (2019) meneliti tentang "Pergeseran Peran Buzzer ke Dunia Politik di Media Sosial” yang menyoroti bagaimana awal pergeseran atau perubahan peran buzzer yang semula berperan sebagai buzzer marketing lalu meluas menjadi buzzer politik (Pemilu 2009, Pilkada 2012, Pemilu 2014 hingga sekarang). Keberadaan buzzer selanjutnya menjadi suatu kebutuhan bagi para aktor politik untuk memperbaiki citra sehingga dapat meningkatkan suara politikus dalam Pemilu serta memanipulasi dan menangkal isu-isu tertentu (Mustika 2019).

Selanjutnya penelitian dengan judul "Salah Kaprah Ihwal Buzzer: Analisis Percakapan Warganet di Media Sosial" yang dilakukan oleh Bambang Arianto (2020) menguraikan tentang sejumlah salah kaprah warganet tentang istilah buzzer maupun peran yang dimilikinya. Istilah buzzer (Arianto 2020) sendiri sering dirujuk sebagi akun media sosial bayaran yang berperan sebagai penyebar hoaks dan disinformasi. Peneliti dalam hal ini juga 
menyatakan bahwa kehadiran buzzer mulanya hanya dikenal dalam dunia bisnis digital sebagai tim yang disewa untuk pemasaran suatu produk dan jasa. Lalu istilah ini berkembang hingga ke ranah politik yang dikenal sebagai "BuzzerRp" politik. Ia melihat bahwa buzzer merupakan upaya memperkuat suatu pesan dengan berbagai kreativitas masing-masing. Baik dalam konteks bisnis (buzzer bisnis) dan politik (buzzer politik), khususnya yang sangat dibutuhkan para kandidat dan partai politik untuk memperkuat pesan kampanye.

Selaras dengan penelitian yang dilakukan oleh Bambang Arianto, Shiddiq Sugiono (2020) dalam penelitiannya yang berjudul "Fenomena Industri Buzzer di Indonesia: Sebuah Kajian Ekonomi Politik Media". Penelitian ini banyak mengungkapkan bahwa buzzer yang mulanya dimaknai sebagai aktor yang bertugas untuk mengamplifikasi pesan di media dalam konteks promosi bisnis telah mengalami pergeseran konsep akibat kontestasi politik di dunia. Hal ini dipengaruhi oleh momentum pemilihan presiden di Amerika Serikat yang dalam hal ini dikotori oleh pesan-pesan provokatif oleh buzzer politik (Sugiono 2020).

Sementara itu di Indonesia sendiri, buzzer turut dimaknai sebagai kaki tangan suatu pihak untuk mencapai tujuan politiknya dengan cara menyampaikan pesan-pesan yang provokatif atau bersifat menyerang isu pribadi. Sehingga istilah buzzer sendiri menjadi konsep yang secara umum berada dalam konteks politik dan memiliki stereotip negatif. Kemudian dalam penelitian ini juga disebutkan bahwa terdapat relasi antara berbagai aktor yang ingin mencapai tujuan politiknya dengan menggunakan buzzer politik. Relasi ini dalam konteks mempertahankan kekuatannya, pemerintah diindikasikan telah menggunakan buzzer politik untuk melakukan perlawanan terhadap serangan konten-konten dari pihak oposisi yang juga diindikasikan menerima imbalan berupa kursi jabatan dalam suatu institusi.

Berbagai penelitian yang dilakukan ini memperlihatkan beragam definisi dalam menerjemahkan istilah buzzer, apa yang dilakukan, motif yang mendasari hingga tujuan atas apa yang mereka lakukan. Sedangkan penulis di sini ingin melihat peran buzzer mengkonstruksi pesan dalam proses pembentukan opini publik di new media. Sehingga mampu membuat pesan tersebut menjadi viral dan dibicarakan khlayak.

\section{Metode}

Penelitian ini diawali dari pemahaman tentang paradigma yang merupakan sebuah realitas buatan manusia sebagai alat untuk mempersepsi alam semesta secara lebih sistematis demi mendapatkan ilmu pengetahuan. Sebagai bandingan, manusia menciptakan garis ekuator, garis lintang, dan garis bujur demi kemudahan menentukan letak geografis sebuah titik di muka bumi. Dengan bantuan paradigma, para ilmuan dapat memetakan disiplin ilmu pengetahuan secara lebih sistematik (Alwasilah 2015). Sedangkan paradigma yang digunakan dalam penelitian ini berupa paradigma kritis postmodernisme (posmo).

Paradigma kritis postmodernisme merupakan sebuah pandangan, kerangka pemikiran atau aliran filsafat yang berkaitan dengan sikap dan cara berpikir yang muncul di abad 20. Aliran ini pun telah digunakan diberbagai bidang seperti, seni, arsitektur, musik, film dan teater. Adapun tujuan keberadaan aliran ini adalah untuk menjawab dan mengkritisi pandangan-pandangan yang telah ada sebelumnya dalam hal mencari solusi atas beragam permasalahan yang dihadapi manusia hari ini serta krisis sosial dan kultural yang tak kunjung usai.

Paradigma postmodernisme juga melihat bahwa kebenaran itu tidak bisa dibayangkan, tetapi manusia harus aktif dalam mencari dan membangun kebenaran itu sendiri serta kreatif dalam memaknai. Segala sesuatu yang ada perlu didekonstruksi karena tidak mampu dalam menemukan kebenaran. Pencetus istilah "postmodernisme" Jean Francois Lyotard menyatakan bahwa setiap narasi besar atau grand narrative yang menjadi strategi terhadap klaim prinsip atas kebenaran, kesejahteraan, makna kehidupan serta moral selanjutnya diganti dengan narasi-narasi kecil dengan segala nilai mitos, spiritual, dan ideologi yang lebih khusus atau spesifik.

Penelitian ini selanjutnya juga menggunakan metode penelitian kualitatif eksploratif dengan strategi studi kasus. Menurut Strauss dan Corbin (Sujarweni 2014) penelitian kualitatif merupakan jenis penelitian yang menghasilkan penemuan-penemuan yang tidak dapat dicapai (diperoleh) dengan menggunakan prosedurprosedur statistik atau cara-cara lain dari kuantifikasi (pengukuran). Penelitian kualitatif secara umum dapat digunakan untuk penelitian tentang kehidupan masyarakat, sejarah, tingkah laku, fungsionalisasi organisasi, aktivitas sosial dan lain-lain.

Hal yang hampir serupa juga diungkapkan oleh Afrizal (2014) bahwa penelitian kualitatif merupakan penelitian ilmu-limu sosial yang mengumpulkan dan menganalisis data berupa kata-kata (lisan maupun tulisan) dan perbuatan-perbuatan manusia serta peneliti tidak berusaha menghitung atau mengkuantifikasikan 
data kualitatif yang telah diperoleh dan dengan demikian tidak menganalisis angka-angka. Tetapi bukan berarti dalam penelitian kualitatif peneliti tabu dengan angka-angka. Karena para peneliti dalam penelitian ini pun perlu untuk mengumpulkan dan menganalisis angka-angka jika dibutuhkan (Afrizal, MA 2014).

Seiring dengan hal tersebut, pada penelitian ini penulis menggunakan pendekatan studi kasus untuk memperoleh hasil yang diinginkan. Studi kasus dapat dimaknai sebagai suatu inkuiri empiris yang menyelidiki fenomena di dalam konteks kehidupan nyata bilamana: batas-batas antara fenomena dan konteks tak tampak dengan tegas dan di mana multisumber bukti dimanfaatkan (Yin 2015). Biasanya strategi studi kasus lebih dikehendaki untuk melacak peristiwa-peristiwa yang bersangkutan tidak dapat dimanipulasi. Ia mendasarkan dirinya pada teknik-teknik yang sama dengan kelaziman yang ada strategi historis, tetapi dengan menambahkan dua sumber bukti yang biasanya tak termasuk dalam pilihan para sejarawan, yaitu wawancara dan observasi sistematik. Kekuatan unik yang berhubungan sepenuhnya dengan berbagai jenis bukti. Baik berupa dokumen, peralatan, wawancara dan observasi.

Data penelitian didasarkan kepada data primer (informasi lapangan/ langsung dari sumber pertama). Pada penelitian ini yang menjadi sumber pertama ialah buzzer yang dipilih melalui teknik snowball sampling. Sedangkan untuk data sekunder (sumber lain atau tidak langsung) seperti dokumen dan bahan audio visual. Teknik pengumpulan data yang digunakan terdiri dari beberapa bentuk yaitu, interview atau wawancara, observasi, analisis dokumen, dan bahan audiovisual. Di samping mewawancarai dua orang informan, penulis juga melakukan observasi dan analisis terhadap postingan cuitan Twitter akun-akun berikut: 1 . @Dennysiregar7, 2. @adearmando, 3. @eko_kuntadhi, 4. @JackParang, 5. @SosmedMata, 6. @ProfYLH, 7. @Lionelbarcalope, 8. @kurawa, 9. @indopolicestate, dan 10.@Suara_Bawah.

Setelah itu dalam hal analisis data dilakukan dengan pembuatan deskripsi detail tentang kasus tersebut dan settingnya. Stake (Creswell 2015) mendukung empat bentuk analisis dan penafsiran data dalam penelitian studi kasus. Pertama, pengelompokkan kategorikal; Dua, melihat satu contoh tunggal dan menarik makna darinya tanpa mencari beragam contoh. Tiga, menetapkan pola dan berusaha menemukan korespondensi antara dua atau lebih kategori. Dan berikutnya peneliti mengembangkan generalisasi naturalistik dari analisis data tersebut. Adapun validasi data dengan menggunakan teknik triangulasi data.

\section{Hasil dan Pembahasan}

\section{Dinamika Peran Buzzer}

Buzzer sebagai sebuah fenomena memiliki keunikan tersendiri. Pada awalnya ia bersifat netral, yaitu sebagai bagian dari suatu rencana marketing yang terdapat pada sebuah perusahaan. Ismail Fahmi, seorang pakar media sosial bahkan menyatakan jika aktivitas buzzer memiliki relasi yang sejalan dengan tugas kehumasan (Lokadata 2019). Hal ini karena keberadaan buzzer sangat berkaitan dengan pembuatan, pengelolaan hingga penyampaian pesan. Namun aktivitas buzzer yang semula netral pun mengalami pergeseran dan berevolusi secara psikologis. Pergeseran maupun perubahan ini pada dasarnya timbul akibat adanya polarisasi yang terbangun dari kontestasi politik. Bukan hanya buzzer, tetapi juga para pendukung fanatik yang dengan otomatis membentuk komunitas atau cluster. Ketika "junjungan" atau idola mereka diserang, maka mereka juga akan langsung membela (CNN Indonesia Connected 2020).

Pemilihan umum yang diadakan dalam kurun satu dekade terakhir di tanah air tidak lepas dari adanya peran buzzer. Peran di belakang layar yang diberikan kepada buzzer berguna untuk mengumpulkan suara rakyat. Tokoh-tokoh politik ataupun partai sangat menyadari kekuatan buzzer dalam menarik perhatian khalayak ataupun simpati rakyat. Sehingga buzzer maupun cyber army kerap dimasukkan ke dalam strategi pemenangan Pemilu/ Pilkada maupun kontestasi politik lainnya. Lama kelamaan hal ini pun ikut mengubah tatanan kehidupan bermasyarakat. Bahkan kehadiran buzzer juga ikut "menggoyang" sendi kehidupan berbangsa dan bernegara. Bagaimana orang memandang teknologi (new media/ internet), fitur-fitur yang terdapat di dalamnya, khususnya beragam platform media sosial, serta keberadaan dan peran netizen (warganet) di ruang virtual tentunya tidak lagi dipandang sebagai hal biasa.

Hal ini dikarenakan kemampuan buzzer dalam mengolah atau mengkonstruksi pesan yang disampaikan dan menyebarkannya secara masif. Terlebih hal ini juga didukung dengan ratusan bahkan ribuan akun yang dapat digunakan secara otomatis dan serentak. Aktivitas buzzer ini bahkan semakin diuntungkan jika akun tersebut memiliki banyak follower. Meskipun tidak semuanya demikian. Di antara akun-akun tersebut juga terdapat akun dengan jumlah follower yang sedikit atau minim. Bahkan ada yang tidak memiliki follower. Selain itu adapula akun buzzer yang dijalankan oleh teknologi (bukan akun sebenarnya) atau dikenal dengan akun bot. 
"Buzzer pada dasarnya tidak selalu terdiri dari orang-orang untuk suatu tugas tertentu. Namun ia lebih kepada sistem. Sedangkan akun-akun buzzer yang ada merupakan produk ke sekian. Kemudian yang menjadi produk akhirnya bisa bermacam-macam. Seperti Undang-undang, penjualan produk, nama baik, ataupun yang pernah saya kerjakan yaitu berupa putusan hakim." (Muamar Arsala, wawancara, 22 April 2020)

Pemanfaatan akun-akun palsu ataupun anonim oleh buzzer ini pernah dikupas dalam tayangan Tech a Look tanggal 8 Oktober 2019 (Umah 2019). Tayangan ini mengungkapkan beberapa jenis akun yang digunakan oleh buzzer antara lain akun bot sebesar $80 \%$, akun cyborg $11 \%$, akun bajakan sebesar $7 \%$ dan penggunaan akun manusia sebanyak $87 \%$. Bervariasinya akun yang digunakan ini menjadikan aktivitas buzzer dapat tersebar secara cepat dan sukar untuk dihentikan.

\section{Konstruksi Pesan Viral Buzzer dalam Proses Pembentukan Opini Publik di New Media}

1. Pola Kerja Buzzer dalam Mengolah Pesan

Peran buzzer pada dasarnya sangat bergantung dari bagaimana mereka dalam mengemas dan menyampaikan pesan ataupun narasi-narasi yang ditujukan kepada khalayak. Buzzer sebagai komunikator dalam hal ini juga memiliki tujuan tertentu maupun hal-hal yang hendak dicapai. Meskipun tidak semua konten yang mereka buat merupakan tanggapan murni atas sebuah isu. Melainkan merupakan pesan yang dibuat sedemikian rupa untuk mempengaruhi publik sebagai komunikan, khususnya bagaimana opini publik dapat berubah arah sebagaimana yang mereka inginkan.

Perkembangan media sosial hari ini pun semakin beragam dan dilengkapi dengan fitur-fitur canggih yang semakin memudahkan buzzer dalam melakukan berbagai aktivitasnya. Seperti menulis postingan (status, tweet, ataupun caption) dan komentar, membagikan link informasi, foto, video, ataupun meme terkait isu-isu publik. Berbagai postingan ini di satu sisi memang terkesan spontan dan bersifat individual. Namun pada kenyataannya tidak selalu demikian.

Pada dasarnya sebagian besar aktivitas buzzer di platform media sosial tidak terjadi begitu saja. Dalam arti sebelum membagikan suatu postingan, buzzer juga dibantu oleh beberapa orang dengan job desk yang berbeda. Sebagaimana skema di bawah ini :

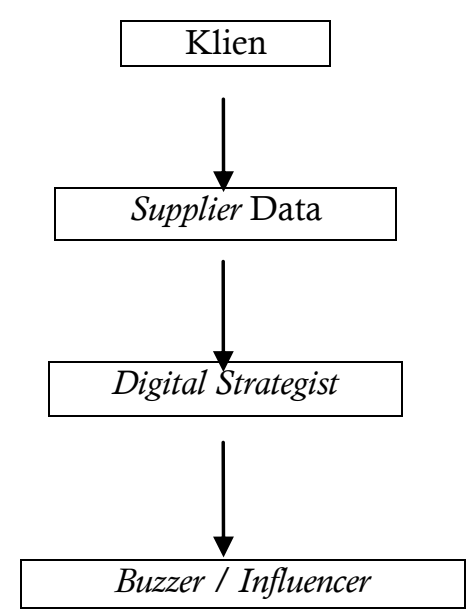

Gambar 2 <Skema Urutan Kerja Buzzer>

(Sumber: Telah diolah kembali berdasarkan hasil wawancara dengan informan)

Skema ini menunjukkan bahwa buzzer secara hierarki berada di urutan paling bawah atau akhir dari aktivitas buzzing sebuah isu/ wacana. Aktivitas buzzer bermula dari adanya klien (individu, kelompok, perusahaan, lembaga atau institusi) yang meminta untuk mengelola sebuah isu. Baik yang berkaitan dengan personal branding (pencitraan terhadap seseorang), company branding (pencitraan perusahaan), marketing product (pemasaran produk) maupun pembuatan konten-konten, narasi atau isu tertentu. Setelah disepakati jenis isu atau wacana yang ingin dibuat, maka selanjutnya bagian supplier data akan mencari dan mengumpulkan data-data yang bisa digunakan untuk membuat isu atau wacana tersebut.

Lalu data-data tersebut akan diriset ulang oleh seorang digital strategist. Hasil riset ini tidak dibuat begitu saja, melainkan diolah dengan menggunakan teori simulacra atau teori simulasi dan media. Teori 
simulacra inilah yang kemudian menjadikan sebuah isu dapat "dimainkan" guna mengubah persepsi ataupun opini masyarakat tentang simbol (tanda) dalam realita tidak seperti apa adanya. Di samping itu secara tidak langsung unggahan ataupun aktivitas buzzer juga bersentuhan dengan ragam ilmu komunikasi. Seperti jurnalistik, dramaturgi, ataupun linguistik. Setelah isu atau konten tersebut dibuat, digital strategist juga berperan untuk membuat tahapan dan merencanakan waktu pemuatan isu atau konten tersebut serta penyebarannya di media sosial. Selanjutnya pada tahap akhir buzzer dan infuencer bertugas untuk menyebarkan dan membahas isu tersebut sesuai waktu yang ditetapkan.

Ismail Fahmi, seorang Pakar Media Sosial, Analisis Drone Emprit \& Kernels Indonesia (CNN Indonesia Connected, 2020) menggambarkan peran buzzer dimulai dari adanya pengumpulan data berupa percakapan yang dilakukan netizen di media sosial. Percakapan tersebut dianalisis dalam arti melihat isuisu yang mendapat perhatian publik. Selanjutnya ditetapkan strategi ataupun rencana untuk mengangkat isu secara lebih luas yang terwakili melalui teks, berita, kultwit ataupun meme. Operasi buzzer pun baru ditandai dengan penyebaran konten (sharing, posting maupun tweet) ke berbagai platform media sosial. Konten-konten ataupun pesan yang disebarkan oleh buzzer ini selanjutnya akan diamplifikasi ataupun direspon oleh user media sosial maupun netizen. Hingga tak jarang konten-konten tersebut justru mampu mengubah pandangan ataupun opini dari publik.

2. Isu-isu Popular di Media Sosial

Pada tahun 2020 lalu, beberapa peristiwa ataupun isu-isu yang beredar di masyarakat luas dan pengguna media sosial dipengaruhi oleh konten-konten yang dibuat, diolah kembali dan dibagikan oleh buzzer. Isuisu popular ini berasal dari berbagai bidang yang memang menarik perhatian khalayak. Portal berita detik.com (2020) dalam artikel yang ditulis oleh Lisye Sri Rahayu mengutip pernyataan Direktur Komunikasi Indonesia Indicator, Rustika Herlambang menyebutkan bahwa ada sejumlah isu popular yang mewarnai tahun 2020. Namun dari berbagai isu tersebut, isu yang menempati posisi teratas adalah tentang covid 19.

Tabel $1<$ Daftar Isu Popular Nasional Tahun 2020>

\begin{tabular}{clcl}
\hline No. & \multicolumn{1}{c}{ Isu Nasional } & No. & \multicolumn{1}{c}{ Isu Nasional } \\
\hline 1. & Covid & 6. & Korupsi \\
2. & Pilkada & 7. & Pertumbuhan Ekonomi \\
3. & Bencana Alam & 8. & Omnibus Law \\
4. & UMKM & 9. & Intoleransi \\
5. & Narkoba & 10. & PHK \\
\hline
\end{tabular}

Sumber : (Sri Rahayu, 2020)

Sedangkan di platform media sosial juga terdapat sejumlah isu popular yang dirangkum melalui penggunaan tagar oleh pengguna. Tagar-tagar yang popular ini, khususnya di platform Twitter ialah sebagai berikut :

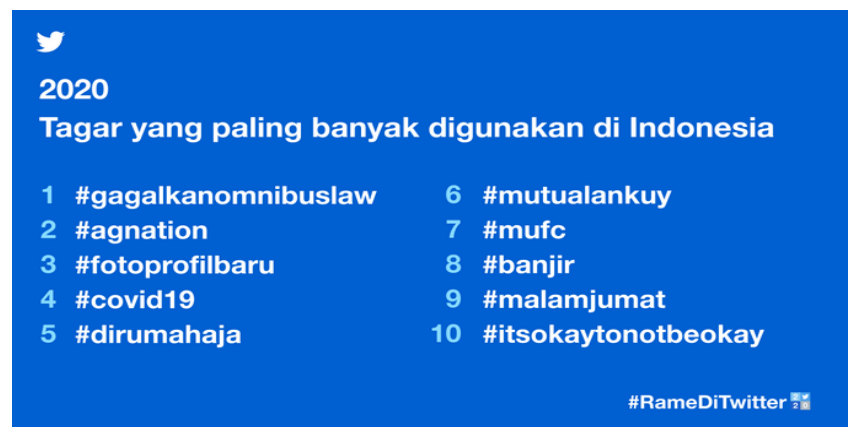

Gambar $3<$ Tagar Terpopular 2020>

Berdasarkan gambar di atas ini dapat terlihat bahwa permasalahan Omnibus Law, covid 19 dan banjir (bencana alam) merupakan hal yang paling menarik perhatian dan banyak dibicarakan oleh netizen. Apalagi isu-isu tersebut juga menjadi fokus pemberitaan ataupun headline (media) sepanjang 2020 lalu. Pembicaraan tentang isu-isu tersebut memang lebih intens terjadinya di platform Twitter. Seperti yang dijelaskan oleh Country Industry Head Twitter Indonesia, Dwi Adriansah bahwa Twitter merupakan media sosial yang digunakan oleh netizen untuk melihat dunia dan mengetahui berbagai informasi 
terbaru yang ada. Terlebih tahun 2020 masyarakat dikondisikan untuk tetap beraktivitas dan berada di rumah.

Selain itu Adriansah juga mengatakan bahwa \#GagalkanOmnibusLaw merupakan hashtag paling popular karena dampaknya yang sangat besar kepada masyarakat. Gerakan ini dilakukan dan dikenal sebagai gerakan sosial untuk membatalkan disahkannya Omnibus Law Cipta Kerja. Omnibus Law sendiri disahkan pada 5 Oktober 2020 dan mendapat atensi luas dari masyarakat. Hal ini terlihat dari sisi pro kontra yang mengiringi berbagai argument ataupun pandangan mereka. RUU Omnibus Law ini dinilai kontroversial dan merugikan masyarakat, khususnya buruh maupun tenaga kerja Indonesia. Beberapa hashtag lain yang ramai digunakan netizen antara lain, \#tolakomnibuslaw, \#MosiTidakPercaya, \#GagalkanOmnibusLaw, \#tolakruuciptakerja, hingga \#DPRKhianatiRakyat yang masing-masingnya juga mendominasi deretan trending topik di Twitter.

Sedangkan isu covid 19 memang telah sejak akhir 2019 menjadi topik hangat di berbagai penjuru dunia. Khususnya sejak ditemukannya kasus pasien positif terinfeksi virus corona di Wuhan, China. Hingga kemudian penemuan kasus ini menyebar ke berbagai negara. Tidak terkecuali di Indonesia.

Lama-kelamaan beragam informasi yang terdapat di platform media sosial maupun percakapan online menjelma menjadi suatu rutinitas harian yang tidak bisa dielakkan, dan mau tidak mau harus dilakukan. Jika tidak ingin ketinggalan informasi ataupun berita yang sedang hangat diperbincangkan. Adanya kebutuhan akan informasi dan keinginan untuk berpendapat (berkomentar) tanpa disadari terkadang menjebak masyarakat maupun pengguna new media untuk selalu merespon setiap hal yang terjadi ataupun dibicarakan. Meskipun tidak semuanya mereka ketahui. Pengguna ataupun netizen ikut berpendapat secara apa adanya ataupun sesuai kadar pengetahuan yang mereka miliki. Baik itu untuk isu yang mereka kuasai maupun yang tidak mereka kuasai. Termasuk di antaranya informasi-informasi yang dirancang sedemikian rupa oleh para buzzer.

Kasus maupun isu yang berkaitan dengan Omnibus Law Cipta Kerja dan covid 19 merupakan dua isu yang paling mendominasi di tahun 2020. Banyak pendapat ataupun komentar-komentar menanggapi kedua persoalan ini. Begitupula dengan sejumlah akun buzzer yang secara "maraton" dan konsisten membagikan postingan (tulisan, meme, dan video) yang berkaitan dengan isu tersebut. Baik itu di media sosial seperti Facebook, Twitter dan Instagram.

Aksi demonstrasi yang dilakukan secara berulang oleh buruh, mahasiswa, akademisi dan sipil yang peduli dengan nasib buruh menimbulkan reaksi pro kontra di tengah masyarakat maupun netizen. Reaksi ini terlihat dari silih bergantinya trending topic linimasa Twitter maupun media sosial seperti Facebook dan Instagram. Baik yang berhubungan dengan demonstrasi maupun Omnibus Law Cipta Kerja sendiri.

Beberapa akun (identik) sebagai buzzer juga turut membagikan maupun mengunggah pesan ataupun konten yang secara tidak langsung memperlihatkan posisi mereka dalam isu tersebut, serta upaya untuk meyakinkan publik, mengubah ataupun membelokkan opini publik. Salah satunya melalui penggunaan bahasa yang mampu menggugah rasa ingin tahu, mengkonfrontasi, menyudutkan ataupun memihak salah satu pihak. Hal ini sebuah kewajaran mengingat peran buzzer tidak dapat dipisahkan dari bagaimana konstruksi pesan yang mereka hadirkan ke hadapan khalayak.
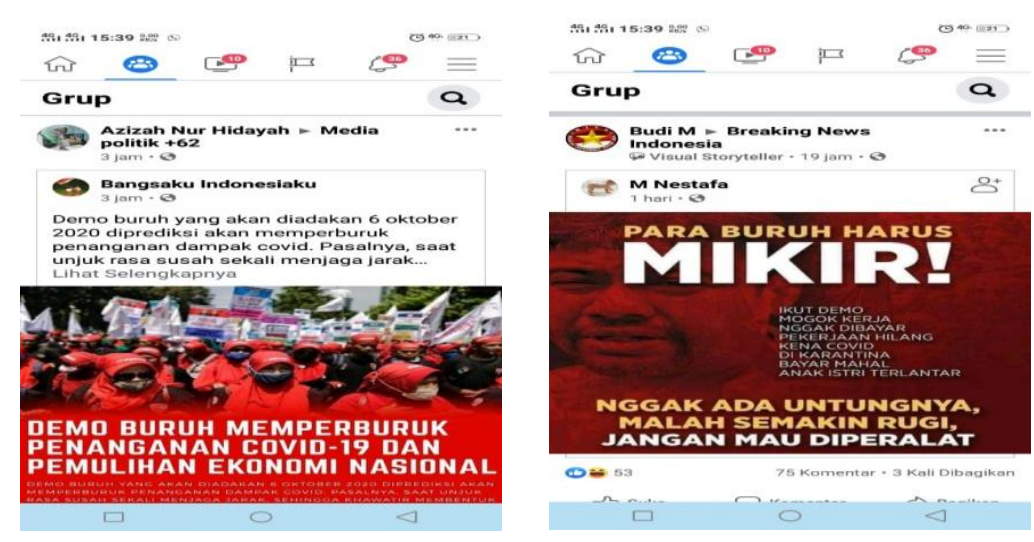

\section{Gambar $4<$ Contoh postingan akun buzzer Tentang Kasus Demonstrasi UU Omnibus Law Cipta Kerja>}


Berdasarkan pengamatan yang penulis lakukan akun-akun buzzer terdapat beberapa karakter yang mewarnai pesan / konten yang mereka bagikan antara lain: 1. Jarang menggunakan bahasa atau katakata formal yang membuka wacana secara sehat di ruang publik. Pola bahasa ataupun kecenderungan berbahasa yang digunakan justru banyak dalam bentuk bahasa keseharian atau tidak formal. Baik itu berupa rangkaian kalimat yang tidak terlalu memikirkan tata bahasa, penggunaan Ejaan Bahasa Indonesia secara baik dan benar maupun bahasa memikat yang menyenangkan untuk dibaca. Sebagian besar dari kalimat ataupun rangkaian kata yang digunakan dan terdapat dalam akun-akun buzzer tersebut justru "menabrak" panduan berbahasa yang baik dan benar yang selama ini menjadi sebuah keharusan. Dua, intensitas postingan bisa seharian atau lebih dari 12 jam. Ketiga kalimat yang digunakan provokatif dan menjelekkan lawan atau membully. Salah satu contohnya pada cuitan akun Twitter Denny Siregar berikut ini:

Tabel 2 <Cuitan akun Twitter Denny Siregar selama Demonstrasi Omnibus Law Cipta Kerja>

\begin{tabular}{|c|c|}
\hline Nama Pemilik Akun & Isi Status/ Tweet/ Caption \\
\hline \multirow[t]{12}{*}{ Denny Siregar } & $\begin{array}{l}\text { Akhirnya saya bisa paham apa yang disebut "tanpa beban" oleh } \\
\text { @jokowi.. Omnibus Law ini adalah manuver besar tanpa beban. Mau } \\
\text { didemo sebesar apapun. UU ini tetap harus jalan. Gak penting tidak } \\
\text { popular. Yang penting perubahan harus terjadi. Sekarang atau tidak sama } \\
\text { sekali }\end{array}$ \\
\hline & $\begin{array}{l}\text { Dulu mereka2 juga yang provokasi "Denny Siregar dicari anak STM", Eh, } \\
\text { malah mereka yang ditangkap. Coba tengok pak@CCICPolri apakah } \\
\text { salah satunya ada yang punya akun @_KingPurwa? } \\
\text { https://t.co/BfV1WHcnHu }\end{array}$ \\
\hline & Emang ada demo? Dimana? Kok nggak kerasa ya? \\
\hline & $\begin{array}{l}\text { Harus gua akui, kebijakan2 yang dibuat @jokowi memang susah } \\
\text { dipahami oleh mereka yang erpikiran pendek, karea kebijakan2 itu visinya } \\
\text { jauh ke depan. Apalagi oleh mereka yang suka permasalahkan hal-hal } \\
\text { remeh seperti kancing jas, logat Inggris sampe halaman kertas Undang2 }\end{array}$ \\
\hline & Tadi tuh ternyata ada demo yaaa... Kok nggak kerasa? \\
\hline & Takut ditangkap, trus bilang Omnibus Law mulia. Kelakuan \\
\hline & $\begin{array}{l}\text { Paham kan, kenapa Omnibus Law itu penting banget sbg dasar supaya } \\
\text { negeri ini kedepannya maju? Kalo gak paham, kelaut aja deh lu, } \\
\text { https://t.co/DMUx5d3E7R }\end{array}$ \\
\hline & $\begin{array}{l}\text { Demo Omnibus Law kemarin di bbrp daerah, sebenarnya menguji kualitas } \\
\text { para kepala daerah yg diharapkan jadi pemimpin nasional. Jadi ingat kata } \\
\text { bokap, "Kualitas pemimpin terlihat dari seberapa kuat ia menerima } \\
\text { tekanan." Bukan dari bagusnya dirinya lewat status } 2 \text { di media sosial }\end{array}$ \\
\hline & $\begin{array}{l}\text { Demolah terus. Karena setiap kali kalian demodan @jokowi berhasil } \\
\text { meredam aksi kalian, investor luar akan melihat itu sebagai kekuatan. } \\
\text { Kepercayaan akan tumbuh dan mrk akan ramai2 datang ke Indonesia. } \\
\text { Itulah yang disebut dibalik masalah selalau ada peluang }\end{array}$ \\
\hline & $\begin{array}{l}\text { Nahh.. Kali ini gua mau puji @aniesbaswedan. Ini usul yang cerdas banet } \\
\text { (tumben). Biar pelajar itu ngerti, mrk paham gak apa yang mrk demokan. } \\
\text { Sekalian ngitung brp total perbaikan halte yg kebakar, } \\
\text { https://t.co/RLN31nOtWf }\end{array}$ \\
\hline & $\begin{array}{l}\text { Temen gua buruh ikut demo Omnibus. Trus dia berhenti dan gak mau ikut } \\
\text { lagi. Kutanya. "Kenapa? Kan katanya perjuangan belon selesai?" Dia } \\
\text { ngamuk. "Soalnya si kadrun2 itu ikutan demo. Ngapain coba?? Kerja aja } \\
\text { nggak, demo segala. Gak mau disamain ma mereka!!" aku kok ngakak ya. }\end{array}$ \\
\hline & $\begin{array}{l}\text { Dari kmrn video ambulans yang lari dari kejaran polisi waktu demo, } \\
\text { sliweran ditempat gua. Kabarnya ambulans sdh ditangkap dan ada dugaan } \\
\text { isinya batu untuk logistik. Peristiwa Mei } 2019 \text { mau mrk ulang. Misi } \\
\text { kemanusiaan disusupi. Mirip ISIS di Suriah } \\
\text { https://t.co/M2Z0VGCGrR }\end{array}$ \\
\hline
\end{tabular}




\begin{tabular}{|c|c|}
\hline \multirow{2}{*}{$\begin{array}{l}\text { Nama Pemilik } \\
\text { Akun }\end{array}$} & Isi Status/ Tweet/ Caption \\
\hline & $\begin{array}{l}\text { Gua juga gak paham, ada Gubernur yang lebih tunduk pada tekanan } \\
\text { massa daripada menjaga amanat UU. Ini Gubernur muka dua, lebih fokus } \\
\text { pada citra dirinya. Gak layak jadi pemimpin nasional, krn kerjaannya } \\
\text { cuman rangkul sini rangkul sana. Jangan ada lagi model bpk prihatin } \\
\text { kedua https://t.co/ITiuRWeo66 }\end{array}$ \\
\hline & $\begin{array}{l}\text { Dalam demo seperti ini sebenarnya yang paling rugi adalah bohir. } \\
\text { Uangnya kepake, tapi tujuannya gak kecapai. Yang kedua adalah pelaku } \\
\text { dilapangan. Dapat duitnya dikit, tapi hidupnya paling terancam. Trus } \\
\text { siapa dong yang untung?? Yang untung yang dapet DP rumah } 500 \text { juta } \\
\text { hahaha }\end{array}$ \\
\hline & $\begin{array}{l}\text { Harus ada bakar2nya, karena itu bagian dr proposal supaya cair bayaran, } \\
\text { https://t.co/QI9NhXbnou }\end{array}$ \\
\hline & $\begin{array}{l}\text { Harusnya utk kerjaan sebesar Omnibus Law ini, gerakkan para jurubicara } \\
\text { yg sudh ditatar utk memahami UU. Seperti kampanye. Ada Adian, } \\
\text { Yasonna, Irma Chaniago dan org2 yg bisa berdebat dan paham masalah. } \\
\text { Trending topik di twitter itu hanya kerjaan org2 medsos yg maenan } \\
\text { proposal }\end{array}$ \\
\hline & $\begin{array}{l}\text { Pak @jokowi kalau Menteri2 bapak hanya mengandalkan bot utk ciptakan } \\
\text { trending di twitter sbg komunikasi, situasi terus begini. Trending topik } \\
\text { bukan komunikasi, tp hanya angka spy proposal dihargai. Itu model lama. } \\
\text { Ubah cara komunikasi, bangun narasi. Itu lbh berguna skrg ini. }\end{array}$ \\
\hline & $\begin{array}{l}\text { Mau nanya, kadrun2 itu ngapain sih mau demo UU cipta kerja? Mereka } \\
\text { kan nganggur }\end{array}$ \\
\hline & $\begin{array}{l}\text { Turunnya marinir memenuhi jalan2 ibukota bukan karena skala demonya } \\
\text { besar. Tapi sebuah pesan dari pemerintah, bahwa UU Omnibus Law ini } \\
\text { dikawal secara serius. Jangan main2 @jokowi kalau tangan besinya sudah } \\
\text { keluar, mereka yg dulunya bilang dia planga plongo, skrg terkaget2. }\end{array}$ \\
\hline & $\begin{array}{l}\text { Untuk adek mahasiswa, kalo kelen pengen seperti kakak2 kelen yg sukses } \\
\text { tumbangkan rezim di98, banyak2lah belajar ke kak @budimandjatmiko } \\
\text { dan kak Adian. Apa bedanya kelen dgn mrk? Mrk tahu apa mrk demokan. } \\
\text { Kalo kelen, baca sepotong, ngerti sepotong, ngamuk segentong }\end{array}$ \\
\hline
\end{tabular}

Sumber : Akun Twitter Denny Siregar @Dennysiregar7

Cara kerja buzzer yang mengkonstruksi pesan sedemikian rupa pada dasarnya menjadikan isu-isu publik ataupun persoalan-persoalan masyarakat yang ada justru tidak dapat dicarikan solusinya. Serta hal ini juga mengurung masyarakat ke dalam cara berpikir lama yaitu menyampaikan pendapat ataupun kritik merupakan suatu bentuk pertentangan, ketidaksukaan ataupun kebencian terhadap pemerintah ataupun pihak-pihak yang selama ini menjadi klien. Padahal dengan kehadiran teknologi dan jaminan yang ada pada UUD 1945 serta dasar negara

Pancasila, masyarakat justru bisa menempatkan dirinya di ruang publik secara lebih terbuka. Bukan hanya melalui cara-cara konvesional. Seperti melalui surat, rapat ataupun dialog-dialog terbatas. Namun sayangnya kesempatan yang ada pada masyarakat ini harus dihadapkan dengan fenomena buzzer yang menjadikan setiap persoalan serupa bola salju yang menggelinding dan membesar dan tidak tahu kapan berhentinya. Kehadiran buzzer yang kerap menciptakan kekisruhan baru melalui intensitas postingan dan konstruksi pesan yang mereka bagikan kepada khalayak malah berubah menjadi tantangan baru yang dewasa ini perlu disikapi secara bijak dan tepat.

Kehadiran platform media sosial hari ini pada dasarnya memberikan kesempatan kepada siapa saja dalam memproduksi dan mendistribusikan pesan yang hendak disampaikannnya. Begitupula dengan buzzer yang memanfaatkan fitur new media untuk mengkonstruksi pesan sesuai apa yang mereka kehendaki. Pesan-pesan yang disebarkan buzzer, lalu menjadi viral pada dasarnya tidak terjadi begitu saja. Sebab untuk menjadikan suatu pesan diminati, tersebar begitu luas atau menjadi viral dan dibicarakan juga memerlukan strategi atau cara-cara tepat untuk mewujudkan itu semua. Di samping persoalan teknis, juga dibutuhkan kejelian dalam membaca situasi dan kondisi dan bisa merangsang sisi-sisi humanis, emosional maupun perasaan target (khalayak/ pengguna new media). Karena cara demikian 
cenderung lebih cepat dalam menarik perhatian khalayak dan membantu dalam penyebaran pesan itu sendiri.

3. Konstruksi Pesan Viral oleh Buzzer dan Opini Publik

Konstruksi pesan pada isu-isu atau konten viral yang dilakukan oleh buzzer serta berperan dalam pembentukan opini publik diawali dengan adanya peristiwa, kejadian atau sesuatu untuk diperbincangkan. Dalam hal ini merujuk kepada hal-hal yang bisa diolah atau dikelola menjadi suatu konten. Peristiwa yang yang telah terseleksi itu pun lalu dirancang oleh tim buzzer dalam bentuk tulisan (status/ tweet/ caption), video, ataupun meme yang diposting dan disebarkan melalui berbagai platform media sosial. Meskipun dalam proses pembuatan atau pengolahan pesan maupun konten tersebut membutuhkan peran sejumlah orang dan dibuat sedemikian rupa, tetap saja dalam penyebarannya membutuhkan algoritma.

Algoritma ialah suatu urutan atau langkah-langkah untuk menyelesaikan masalah. Secara ringkas algoritma dapat dikatakan mengatur arus informasi yang beredar di dalam sistemnya. Algoritma pada media sosial khususnya Facebook, Twitter dan Instagram tidaklah sama. Sebagaimana yang diterangkan oleh Ane Sovia (its.ac.id, 2020) bahwa penyampaian konten pada media sosial tergantung dari bagaimana media sosial tersebut bekerja. "Rata-rata algoritma yang digunakan platform media sosial biasanya merekam kebiasaan pengguna." Dalam arti media sosial secara lebih intens dan fokus dengan hal-hal yang disukai oleh si pengguna. Algoritma ini secara tidak langsung membantu pengguna dalam menyaring dan memilih hal-hal menarik ataupun yang disukai pengguna tersebut.

Pada ketiga platform media sosial tadi terdapat formula yang berlainan untuk menyeleksi kebiasaan yang dimiliki oleh pengguna.

- Akun Facebook pada awalnya lebih sering menampilkan berbagai unggahan dari teman-teman pengguna di bagian news feed-nya, terlepas dari pengguna menyukai (berminat) atau tidak. Sementara saat ini algoritma Facebook bekerja dengan menyampaikan konten-konten khusus yang diminati oleh pengguna. Sehingga hal-hal yang tidak diminati atau tidak disukai pengguna secara otomatis tidak akan ditampilkan di feed-nya.

- Akun Twitter menggunakan dua bentuk algoritma yaitu secara real time dan juga berdasarkan popularitas dan umpan balik tweet.

- Akun Instagram lebih menggunakan pola menampilkan unggahan-unggahan dari pengguna lainnya yang sering berinteraksi dengan kita ataupun yang sering dikunjungi profilnya.

Walaupun ketiga platform ini secara sekilas memiliki kriteria sendiri dalam penggunaan algoritma, akan tetapi pada masing-masingnya juga dapat ditarik sebuah kesamaan yaitu pola yang digunakan cenderung lebih melihat aktivitas, kebiasaan maupun kesukaan si pengguna. Format ini juga menggambarkan bahwa media sosial meskipun ia merupakan bentuk ruang publik baru, namun ia juga mempersonalisasi aktivitas penggunanya. Sehingga hal ini yang kemudian membantu dalam pemasaran, khususnya menaikkan rating topik-topik tertentu dengan cara menyajikan konten yang baik dan tepat sasaran. Hal inilah yang kemudian membantu buzzer ataupun digital strategist dalam membuat kontenkonten yang menarik perhatian khalayak

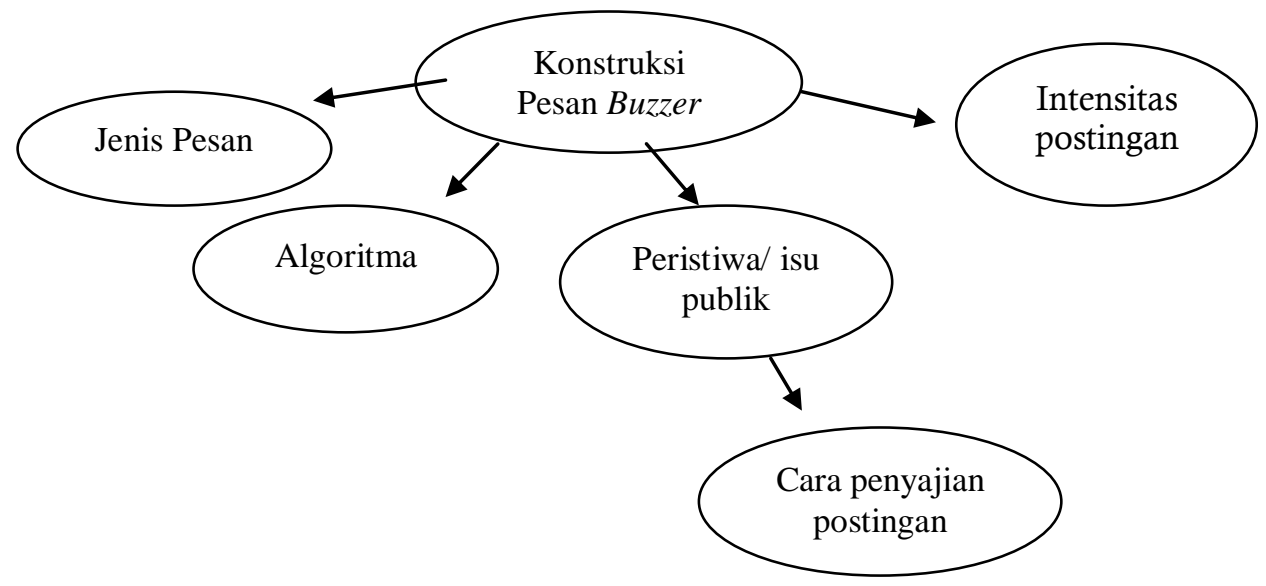

Gambar 5 <Konstruksi Pesan pada Isu yang Diviralkan Buzzer dalam Pembentukan Opini Publik> 
Pola ini pun sangat mempengaruhi konten-konten yang mereka bagikan lalu menjadi viral. Biasanya untuk sebuah isu minimal terdapat tiga konten (tulisan/ video/ atau meme) yang dibagikan per harinya. Dan bisa mencapai belasan atau puluhan jika dihitung dalam setiap pekan ataupun bulan. Hal inilah yang membuat postingan yang dibagikan buzzer bisa melekat pada diri pengguna, mempengaruhi dan membentuk opini mereka. Karena postingan-postingan itu dibagikan secara intens (terus-menerus) oleh banyak akun buzzer. Sehingga perhatian pengguna selalu tertuju pada isu tersebut. Namun sayangnya tidak semua pesan (konten-konten) tersebut berisi hal-hal esensial, penting ataupun membicarakan hakikat dari suatu persoalan yang pada dasarnya merupakan inti dari suatu penyampaian pendapat ataupun gagasan.

Secara sederhana skema/ pola proses pembentukan opini publik oleh buzzer di new media atau platform media sosial adalah sebagai berikut :

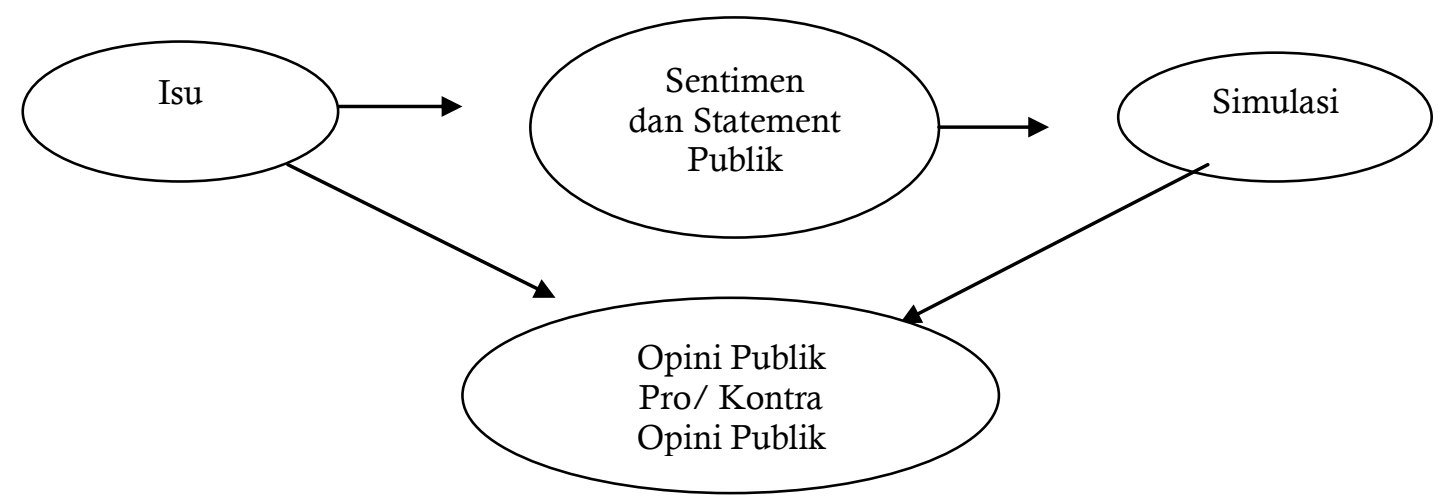

\section{Gambar $4<$ Pola Pembentukan Opini Public $>$}

(Sumber: Telah diolah kembali oleh penulis)

Pesan-pesan buzzer relatif menampilkan karakter dunia postmodern yang membuat tidak ada lagi batas mengenai apa yang boleh atau tidak boleh disampaikan, dipertontonkan, disuguhkan di dalam media. Segala sesuatunya pun ditampilkan secara "telanjang". Beberapa hal yang menjadi kecenderungan dalam postmodern yaitu segala sesuatu menjadi over-signified (tubuh menjadi simbol atau tanda apapun), segala sesuatu menjadi over-exposed (setiap komponen tubuh menjadi elemen komunikasi), menjadi over narrated (apapun tentang tubuh diceritakan, dibicarakan, dipertontonkan)."Ketika segala sesuatunya over-signified, overexposed, dan over narrated, kredibilitas nilai-nilai moralitas yang ada di baliknya lenyap" (Piliang, 2004).

Selanjutnya pesan (konten/ narasi) yang ditampilkan oleh buzzer ini pun tidak lagi memiliki kedalaman. Tapi sebaliknya yang disajikan hanya berupa kedangkalan (depthlessness) dan bersifat permukaan (immanency) atau permukaan komunikasi yang datar, yang hampa makna. Serta mengumbar citra, yang memamerkan setiap tanda, yang menggelar setiap makna, tetapi menetralisir maknanya. Saat ini apa yang dikatakan oleh Piliang (2004) dalam buku Dunia yang Berlari (Mencari Tuhan-Tuhan Digital) ini memperlihatkan bahwa:

"Apa yang menjadi obsesi di dalam wacana postmodernisme bukanlah nilai-nilai moralitas, melainkan nilai-nilai keterpesonaan (fascination) dan ekstasi. Dunia postmodernisme adalah dunia permainan total - permainan di setiap lini kehidupan. Di dalamnya ritual mendapatkan tempatnya yang baru dan yang disebut ritual tak lain dari permainan dan ritual penampilan itu sendiri" (Piliang, 2004).

Sebab itu pada era new media ataupun postmodernisme akan sulit ditemui individu (pengguna) yang masih mementingkan norma atau nilai-nilai yang selama ini dipegang atau tabu. Berbagai informasi yang diproduksi ataupun diterima tidak lagi memperhatikan unsur-unsur komunikasi, tujuan maupun etika komunikasi. Setiap orang cenderung menerima informasi apa saja yang ada pada gawainya, apalagi bila informasi itu sedang jadi topik perbincangan hangat atau pun viral. Di sinilah kemudian konten-konten dari buzzer menjadi lebih cepat diserap, tanpa didahului dengan cek dan ricek ataupun pertimbangan tentang baik buruk, benar atau salah.

Jonah Berger (Berger, 2014) dalam bukunya Contagious - Rahasia di Balik Produk dan Gagasan yang Populer menyebutkan setidaknya ada enam alasan yang menyebabkan orang-orang (pengguna new 
media) dapat dengan cepat dan terkesima dengan segala sesuatu yang viral. Pertama yaitu Social Currency (Mata Uang Sosial), kedua, adanya Trigger (pemicu). ketiga, Emotion (emosi). keempat, Public (umum), kelima, Practical Value (nilai praktis) dan terkahir keenam, Story (cerita).

Jika kehadiran buzzer terus dibiarkan dan tetap mendapatkan porsi seperti saat ini, maka hal ini dapat mengganggu komunikasi di ruang publik, menghilangkan efektivitas komunikasi serta menjadi ancaman bagi demokrasi di tanah air. Sebab buzzer tidak hanya dapat dipandang sebagaibbb kekeliruan dalam pemanfaatan teknologi tetapi juga memperlihatkan bahwa pemerintah ataupun pihak-pihak berwenang belum mampu mengatasi dampak-dampak buruk teknologi. Baik dari sisi kebijakan ataupun tindakan preventif untuk itu semua. Padahal telah banyak protes ataupun laporan hukum yang diajukan masyarakat tentang aktivitas buzzer di ruang publik.

Pembiaran terhadap aktivitas buzzer, khususnya buzzer politik dapat menimbulkan stigma di masyarakat bahwa pemerintah ataupun pihak-pihak yang menggunakan jasa buzzer ikut menjadi bagian dari propaganda untuk mengelabui rakyat. Karena pemerintah tidak berani secara jujur, jernih dan benar dalam menyampaikan sebuah informasi ataupun hal-hal yang berkaitan dengan program kerja, kebijakan ataupun aturan yang dikeluarkan selama ini. Padahal pemerintah sendiri memiliki kekuatan administratif maupun para pejabat pembantu yang seharusnya berperan lebih banyak dalam menyampaikan, menjelaskan ataupun menguraikan persoalan ataupun kebijakan publik. Sebut saja juru bicara Presiden, menteri sekretaris negara maupun para menteri lainnya yang memiliki tanggungjawab sesuai dengan lembaga pemerintah tempat ia berada.

Lalu tidak menutup akses bagi masyarakat untuk mengutarakan pendapatnya secara terbuka, bebas dan bertanggungjawab. Sehingga pada akhirnya pemerintah dan jajarannya secara tidak langsung telah berperan dalam literasi media dengan mengajarkan kepada masyarakat untuk mampu memanfaatkan ruang publik (new media) secara tepat, baik dan benar. Tanpa takut dikebiri hak berpendapat dan mengkritik yang menjadi hak dasar sebagai warga negara Indonesia.

\section{Simpulan}

Dapat disimpulkan bahwa 1) Kehadiran buzzer di new media (media sosial) sudah ramai dibicarakan sejak satu dekade terakhir. Khususnya sejak Pilkada 2012. 2) Kehadiran buzzer dengan segala pesan ataupun konten menjadi ruang publik baru bagi siapa saja di new media. Setiap orang bebas berpendapat, menyatakan pikiran ataupun berkomentar. 3) Buzzer mengkonstruksi pesan sedemikian rupa sehingga bisa mengubah opini publik. 4) Konstruksi pesan viral yang disampaikan di media sosial oleh buzzer bersandar pada isi, intensitas atau waktu tertentu.

\section{Referensi}

Afrizal, MA, Prof. D. 2014. Metode Penelitian Kualitatif. Jakarta: PT Raja Grafindo Persada.

Alwasilah, A. Chaedar. 2015. Pokoknya Studi Kasus-Pendekatan Kualitatif. Bandung: Kiblat Buku Utama.

Anon. 2019. "Kompas TV."

Arianto, Bambang. 2020. "Salah Kaprah Ihwal Buzzer: Analisis Percakapan Warganet Di Media Sosial." Jurnal Ilmiah Ilmu Pemerintahan 5(1):1-20. doi: 10.14710/jiip.v5i1.7287.

Bramasta, Dandy Bayu. 2019. "Mengenal Buzzer Influencer Dampak Dan Fenomenanya Di Indonesia."

CNN Indonesia Connected. 2020. "Saat Buzzer Jadi Sorotan."

Creswell, John W. 2015. Penelitian Kualitatif Dan Desain Riset. Yogyakarta: Pustaka Pelajar.

Haryanto, Agus Tri. 2020. "Riset: Ada 175,2 Juta Pengguna Internet Di Indonesia."

Jati, Wasisto Raharjo. 2016. "Aktivisme Kelas Menengah Berbasis Media Sosial: Munculnya Relawan Dalam Pemilu 2014." Jurnal Ilmu Sosial Dan Ilmu Politik 20(2):147. doi: 10.22146/jsp.24795.

Kietzmann, Jan H., Kristopher Hermkens, Ian P. McCarthy, and Bruno S. Silvestre. 2011. "Social Media? Get Serious! Understanding the Functional Building Blocks of Social Media." Business Horizons 54(3):241-51. doi: 10.1016/j.bushor.2011.01.005.

Lokadata. 2019. "Lokadata."

Mustika, Rieka. 2019. "Pergeseran Peran Buzzer Ke Dunia Politik Di Media Sosial." Diakom: Jurnal Media Dan Komunikasi 2(2):144-51. doi: 10.17933/diakom.v2i2.60.

Nailufar, Nibras Nada. 2019. "Nailufar_Buka-Bukaan Soal Buzzer.” Retrieved March 12, 2020 (https://www.kompas.com/tren/read/2019/10/09/060029265/buka-bukaan-soal-buzzer-1pengakuan-denny-siregar-dan-pepih-nugraha-soal).

Sugiono, Shiddiq. 2020. "Fenomena Industri Buzzer Di Indonesia: Sebuah Kajian Ekonomi Politik Media." 
Communicatus: Jurnal Ilmu Komunikasi 4(1):47-66. doi: 10.15575/cjik.v4i1.7250.

Sujarweni, Y. Wiratna. 2014. Metodologi Peneleitian. Yogyakarta: PT Pustaka Baru.

Syarief, Fauzi. 2017. "Pemanfaatan Media Sosial Dalam Proses Pembentukan Opini Publik (Analisa Wacana Twitter Sby)." Jurnal Komunikasi 3(September):2579-329.

Umah, Anisatul. 2019. "Bukan \#Covid 19, Ini Hashtag Paling Ramai Di Twitter 2020." Www.Cnbcindonesia.Com. Retrieved (https://www.cnbcindonesia.com/tech/20201212173746-37208653/bukan-covid19-ini-hashtag-paling-ramai-di-twitter-2020).

Yin, Prof. Dr. Rober. K. 2015. Studi Kasus Desain \& Metode. 1st ed. Jakarta: Rajawali Pers. 